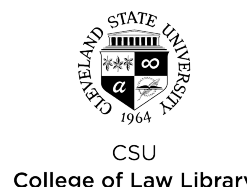

Cleveland State University

College of Law Library

\title{
EngagedScholarship@CSU
}

$10-2010$

\section{Justice John Paul Stevens - His Take on Takings}

\author{
Alan C. Weinstein \\ Cleveland-Marshall College of Law, Cleveland State University, a.weinstein@csuohio.edu
}

Follow this and additional works at: https://engagedscholarship.csuohio.edu/fac_articles

Part of the Constitutional Law Commons, Land Use Law Commons, and the Property Law and Real Estate Commons

How does access to this work benefit you? Let us know!

\section{Repository Citation}

Weinstein, Alan C., "Justice John Paul Stevens - His Take on Takings" (2010). Law Faculty Articles and Essays. 1055.

https://engagedscholarship.csuohio.edu/fac_articles/1055

This Article is brought to you for free and open access by the Faculty Scholarship at EngagedScholarship@CSU. It has been accepted for inclusion in Law Faculty Articles and Essays by an authorized administrator of EngagedScholarship@CSU. For more information, please contact research.services@law.csuohio.edu. 


\title{
Commentary
}

\section{Justice John Paul Stevens- His Take on Takings}

\author{
Alan Weinstein
}

\section{INTRODUCTION}

Justice John Paul Stevens was appointed to the Supreme Court by President Gerald R. Ford and took his seat on the Court on December 19, 1975. Stevens announced his retirement on April 9, 2010, and his seat will be occupied by Solicitor General Elena Kagan, the former Harvard Law School dean who was confirmed on August 5.

This commentary reviews and analyzes Stevens's role in shaping the Court's views on the takings issue in land use regulation.

Justice Stevens's more than 34 years on the Court span almost the entire modern era of the Court's land use jurisprudence. After the Court's two seminal rulings on the constitutionality of zoning in 1926 (upholding the constitutionality of zoning against a facial challenge in Euclid) $^{1}$ and in 1928 (striking down a zoning provision as applied to a particular property in Nectow) $)^{2}$ the Court effectively withdrew from the arena of zoning litigation for almost 50 years, leaving the development of a body of law governing land use to the state courts.

Not until 1974, 46 years after $\mathrm{Nec}$ tow, did the Court again consider the constitutionality of a zoning ordinance, upholding a zoning code's restrictive definition of "family" in Village of Belle Terre. ${ }^{3}$ Since its ruling in Belle Terre, the Court has decided more than 30 cases dealing with land use regulation or closely associated issues such as housing codes. John Paul Stevens is the only justice who was on the Court during the entire post-Belle Terre period in which the Court has defined the constitutional boundaries for land use regulation. One of the two areas where Justice Stevens made his most significant contributions to the Court's land use jurisprudence involves takings. ${ }^{4}$

The chart on pages 6 and 7 provides a chronological view of the positions Justice Stevens took in each of these cases, which are discussed below.

\section{THE EARLY YEARS}

Justice Stevens's pivotal role in shaping the Court's views on the takings issue has been discussed and analyzed previously, particularly by John Echeverria and Richard Lazarus ${ }^{5}$ in articles published in 2006, the year after Stevens authored the majority opinions in Kelo ${ }^{6}$ and San Remo, ${ }^{7}$ two of the three takings cases decided by the Court in 2005. Both authors credit Stevens with astutely crafting a majority that would favor his measured view of the takings clause rather than the doctrinaire "property rights" view espoused by Justice Antonin Scalia.

Justice Stevens only gradually grew into his role as the successful rival to Justice Scalia's property rights vision of the takings clause. In Penn Central, ${ }^{8}$ the Court's first land use regulatory takings case in the post-Belle Terre era, decided in 1978, Stevens, along with Chief Justice Warren Burger, joined Justice William Rehnquist's dissenting opinion that argued the landmark designation of New York's Grand Central Terminal was a taking.

Six members of the Court rejected the takings claim, finding that neither the designation of individual land- marks (like Grand Central) as opposed to the designation of historic districts, nor the fact that the landmark commission had turned down Penn Central's application to construct a high-rise office building atop the terminal, constituted a taking. Justice Rehnquist's dissent focused on the unfairness of landmark designation of selected individual buildings, which he saw as imposing substantial costs on relatively few property owners for the benefit of the city as a whole, concluding: "It is exactly this imposition of general costs on a few individuals at which the "taking' protection is directed."9

Echeverria argues, and I concur, that there was no incongruity in Justice Stevens's joining with the dissenters in Penn Central. ${ }^{10}$ A concern about whether a government regulatory program applies generally, as opposed to singling out specific property owners for special burdens, has been a keynote of his takings jurisprudence. In Penn Central, Stevens's concern about not singling out particular property owners to bear burdens not generally shared by others was a major theme in Justice Rehnquist's dissent. Thus, Rehnquist's view was far more attractive to Stevens than the majority's argument that there was no taking because the designation of individual landmarks occurred in the context of a comprehensive plan to preserve structures of notable historic or aesthetic interest; the owner of any given landmark building enjoyed the benefits that accrued from the fact that many other buildings were also designated. ${ }^{11}$ 
grandmother to have her own grandchild live in the home she shared with her son and his child because its narrow definition of "family" barred the two grandchildren from living together, because they were cousins rather than siblings.

Over the next several years, Justice Stevens continued to vote with Chief Justice Burger and Justice Rehnquist in takings cases. For example, in Kaiser Aetna,$^{12}$ decided a year after Penn Central, both Stevens and Burger joined Rehnquist's majority opinion, which found a taking when the federal government demanded that a private marina allow public access to a channel dredged so members of the marina could have access to the ocean. Rehnquist's rationale for finding a taking in Kaiser Aetna, that requiring public access "would result in an actual physical invasion of the privately owned marina," ${ }^{13}$ would become a "categorical" takings rule in 1982: Government action that results in a permanent physical occupation of property is always a taking. ${ }^{14}$ Stevens, again with Rehnquist and the chief justice, agreed, joining Justice Marshall's majority opinion in Loretto finding that a government regulation, which required certain property owners to allow cable providers to affix their equipment to the owners' buildings in exchange for a token fee, was a taking. As will be seen later in Stevens's dissent in First English and majority opinion in Tahoe-Sierra, the temporal aspect of a challenged regulation would be an important factor in Stevens's view of the takings clause, and so the permanence of the physical occupation in Loretto, in addition to the fact that only certain property owners were singled out under this statute, was no doubt a telling point for him.

We can also see Justice Stevens's developing view of the takings clause

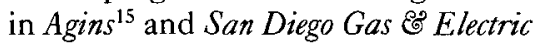
Co. ${ }^{16}$ the two takings cases decided between Kaiser Aetna and Loretto, and in Moore v. City of East Cleveland, ${ }^{17}$ a 1977 case involving a discriminatory housing ordinance.

In Agins, Justice Powell's opinion for a unanimous Court rejected a facial challenge to a zoning ordinance that restricted the density of development on the plaintiff's property. What makes the Agins opinion noteworthy, however, is that it announced a new "two-part" takings test: "The application of a general zoning law to particular property effects a taking if the ordinance does not sub- stantially advance legitimate state interests ... or denies an owner economically viable use of his land ... [TT]he question necessarily requires a weighing of private and public interests." ${ }^{18}$ It was no surprise that Justice Stevens joined this opinion since he had anticipated the substantive due process prong of Agins $^{19}$ in his concurring opinion in Moore.

In Moore, a municipal housing code made it a crime for a grandmother to have her own grandchild live in the home she shared with her son and his child because its narrow definition of "family" barred the two grandchildren from living together, because they were cousins rather than siblings. Six members of the Court had no problem striking down the ordinance on substantive due process grounds, ${ }^{20}$ but Justice Stevens's concurring opinion argued that the ordinance was actually a taking of Mrs. Moore's property. Stevens argued that Justice Sutherland's majority opinion in Euclid v. Ambler supported his view because it "fused the two express constitutional restrictions on any state interference with private property that property shall not be taken without due process nor for a public purpose without just compensation into a single standard: 'Before (a zoning) ordinance can be declared unconstitutional, (it must be shown to be) clearly arbitrary and unreasonable, having no substantial relation to the public health, safery, morals, or general welfare." 21

In 1981, Justice Stevens, along with Chief Justice Burger and Justice Rehnquist, joined Justice Blackmun's majority opinion in San Diego Gas dismissing a takings claim on the ground that there had not been a final determination in the California courts as to whether a taking had occurred. What is interesting about Stevens's position in San Diego Gas is that he, as well as Burger, declined to join Rehnquist's concurring opinion that stated he "would have little difficulty in agreeing with much of what is said in the dissenting opinion of Justice Brennan."22

Justice Brennan's dissent, joined by Justices Stewart, Marshall, and Powell, argued that there had been a final ruling below on the issue of whether a compensatory remedy was required for a taking - the California Supreme Court had denied review of a lower court ruling that no compensatory remedy was available for a taking - and that "once a court establishes that there was a regulatory 'taking,' the Constitution demands that the government entity pay just compensation for the period commencing on the date the regulation first effected the 'taking' and ending on the date the government entity chooses to rescind or otherwise amend the regulation." 23 The view that a "temporary taking" required payment of compensation would subsequently be "agreed with" by Justice Rehnquist in his majority opinion in First English, ${ }^{24}$ from which Stevens would dissent. His position in San Diego Gas suggested as much, and provided a strong hint that the temporal aspect of a challenged regulation would be an important factor in Stevens's view of the takings clause.

The Court ruled on four more takings cases associated with land use, and one eminent domain case, between San Diego Gas and the "1987 Trilogy" of takings cases (Keystone, First English, and Nollan), that would transform the Court's takings jurisprudence and clearly reveal Justice Stevens's views on the takings issue. But by 1985 , these pre-Trilogy cases showed that Stevens no longer shared Justices Burger and Rehnquist's view of the takings clause.

Justice Stevens continued to vote with Chief Justice Burger and Justice Rehnquist in the first two cases decided after San Diego Gas. As discussed above, Stevens joined Justice Marshall's majority opinion in Loretto announcing that a permanent physical invasion of private property was a "categorical" per se taking. And in Midkiff, ${ }^{25}$ a 1984 eminent domain case, he joined Justice O'Connor's. opinion for a unanimous Court, holding that a Hawaiian land reform measure enacted to remedy a concentration of land ownership was a lawful use of the eminent domain power. But the following year, in Williamson County, ${ }^{26}$ Stevens wrote separately for the first time in a takings case and made clear that he saw the takings clause differently than Burger and Rehnquist. 
Williamson County was the Court's third failed attempt in five years to rule on the question of whether a compensatory remedy was required if a court found there had been a temporary regulatory taking of private property. The Court's first two attempts, Agins and San Diego Gas, had failed on procedural grounds; Williamson County met the same fate. ${ }^{27}$ Agins had effectively established an "application requirement" ripeness rule for an as-applied compensatory taking claim. In Williamson County, the Court added two additional ripeness requirements for an as-applied claim.

Justice Blackmun's majority opinion, joined by Justices Burger, Rehnquist, Brennan, Marshall, and O'Connor, held that a federal court takings claim was not ripe until a claimant could demonstrate that: (1) he had sought, and been denied, a variance from the challenged ordinance and (2) no compensatory takings remedy was available in state court. Because the plaintiff in Williamson County had failed to seek a variance, the majority ruled the case was not ripe, reversed a Tennessee court's award of compensatory damages for the alleged taking, and remanded the case without ruling on the compensatory question. Stevens, while concurring in the judgment, wrote separately to oppose the concept that the takings clause required a compensatory remedy for a "temporary taking."

Justice Stevens's concurring opinion claimed that the "[t]emporary harms resulting from a regulatory decision fall into two broad subcategories: (1) those that result from a deliberate decision to appropriate certain property for public use for a limited period of time and (2) those that are a by-product of governmental decision making." 28 Stevens then argued that while the first subcategory "is correctly characterized as a 'temporary taking,' [t]he second subcategory is fairly characterized as an inevitable cost of doing business in a highly regulated sociery." 29 In Stevens's view, compensation is required only for the first subcategory. As long as government has acted fairly and in good faith, delays in regulatory approvals caused by disputes over governmental decisions that impose costs on property owners do not require compensation, even if the government decision proved to be wrong. Stevens would ultimately garner a majority of the Court for this view 17 years later in Tahoe-Sierra.

A year after Williamson County, Justice Stevens broke with Justices Burger and Rehnquist to author the majority opinion in McDonald, Sommer $\mathscr{G}$ Frates $v$. Yolo County, ${ }^{30}$ in which the Court again declined to address the compensation question on ripeness grounds. In Yolo County, the plaintiff had claimed a taking after the denial of its subdivision proposal. Stevens's opinion held that the claim was not ripe because the decisions below in the California state courts "leave open the possibility that some development will be permitted" 31 if the plaintiff submitted a second development proposal; however, Stevens also noted that repeated "futile" applications need not be made. ${ }^{32}$ Justice White's dissent, joined by Justices Burger, Powell and Rehnquist, argued that the subdivision denial was a final decision that effected a taking; but Rehnquist, joined by Powell, declined to join the final part of Justice White's dissent claiming that compensation was required for the temporary taking, arguing that the compensation question in this case should first be addressed by the courts below.

\section{THE 1987 TAKINGS TRILOGY}

The Court finally addressed the compensation question the next year in First English, ${ }^{33}$ one of the trilogy of takings cases the Court decided in 1987. The Court had seen only one new justice appointed since its last substantive takings decision in Loretto in 1982, but that appointment was significant. In 1986, Chief Justice Burger announced his retirement and President Reagan nominated Justice Rehnquist as the new chief justice; D.C. Court of Appeals Judge Antonin Scalia took Rehnquist's seat. Justice Scalia quickly took a leading role as an advocate for the "property rights" view of the takings clause ${ }^{34}$ and for the following two decades he and Justice Stevens would be intellectual, and ultimately "political," adversaries on the takings question. ${ }^{35}$

Justice Stevens's view prevailed in Keystone, the first takings case decided that term, while the view favored by Chief Justice Rehnquist and Justice Scalia prevailed in the next two, First English and Nollan. In Keystone Bituminous Coal Association v. DeBenedictis, ${ }^{36}$ Stevens's majority opinion upheld a Pennsylvania statute prohibiting mining that caused subsidence of the surface that was similar to the statute the Court had declared unconstitutional 65 years earlier in Pennsylvania Coal Co. ข. Mahon. ${ }^{37}$ Stevens distinguished Keystone from Pennsylvania Coal by stressing that the state legislature, in enacting the statute at issue in Keystone, sought to address important public interests by minimizing subsidence, whereas the act struck down in Pennsyluania Coal sought merely to balance the private economic interests of the coal companies against the private interests of the surface owners. Analyzing the statute under both the first prong of Agins and the numerous takings cases in which the Court denied takings claims when government "merely restrains uses of property that are tantamount to a public nuisance," 38 Stevens concluded that the statute served a substantial public interest in preventing activities similar to public nuisances, then found that the statute did not cause a deprivation in value significant enough to satisfy the burden required to find a regulatory taking under Agins's second prong. Rehnquist argued in dissent that there was no significant difference between the current statute and the act struck down in Pennsylvania Coal, so the 1922 decision was controlling and the statute was a taking of property.

One point on which Justice Stevens and Chief Justice Rehnquist disagreed in Keystone would play an important role in future takings cases. The "segmentation" issue involves how the Court would define the property interest to be evaluated for takings purposes. The more narrowly a property interest is defined the more likely a taking will be found. An example of this would be defining the property 
Moore claimed city housing ordinance violated due process clause of 14 th

Moore v. City of

East Cleveland

431 U.S. $494(1977)$

Amendment; Ohio Ct. App. confirmed

violation; Supreme Court reversed;

ordinance bore no rational relationship to

permissible state objectives

\section{Penn Gentral v. City}

of Nere York

Penn Central appealed N.Y. Ct. App.

decision holding city's landmark

438 U.S. 104 (1978)

preservation act as applied to Grand Central

Station did not constitute a taking; Supreme Court affirmed

United States brought action against marina owners claiming their marina was subject to

Kaiser Aetna v. U.S. navigational servitude; $\mathrm{C}$. App. held in favor 444 U.S. 164 (1979) of United States; Supreme Court reversed and held compensation was required if United States wanted marina open to public access

Agins v. City of California Supreme Court held city did not

Tiburon violate $5 \mathrm{th} / 14$ th Amendments by restricting future development of property; Supreme Court affirmed

City rezoned industrial land; impacted petitioners' property; Cal. Ct. App. denied

San Diego Gas :

Electric Co. v. City

of San Diego

450 U.S. 621 (1981)

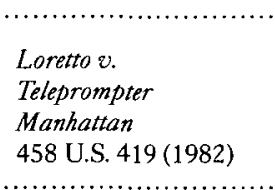

Hawaii Housing
Authority v. Midkiff
467 U.S. $229(1984)$

Court dismissed for lack of jurisdiction (Ct.

App. decision not final)

N.Y. Ct. App. held that temporary permanent occupation of property did not constitute a taking; Supreme Court reversed/remanded for state court to determine appropriate compensation

Hawaii Land Reform Act (to end concentrated land ownership) held unconstitutional by U.S. Ct. App.; Supreme Court reversed and remanded; act did not violate 5 th Amendment Note: Marshall did not participate

Bank sued claiming zoning laws constituted

Williamson Country

RPC v. Hamilton

Bank a taking; Ct. App. reinstated damages as just compensation, petitioner sought cert; Supreme Court reversed and remanded

473 U.S. 172 (1985) Note: Powell did not participate

Landowner's subdivision plan rejected by county planning commission; landowner

MacDonald,

Sommer \& Frates $v$.

Yolo County

477 U.S. $340(1986)$

claimed land restricted; constituted

deprivation of entire economic use; trial court held complaint failed to state c/a; $\mathrm{Cal}$.

Cit. App. affirmed, Supreme Court affirmed; county board had not issued final definitive position regarding zoning restrictions

Coal co. claimed portion of $\mathrm{Pa}$. act that

Keystone Bituminous Coalv. DeBenedictis 480 U.S. 470 (1987) regulated subsurface mining under structures constituted taking; District Ct. held for Pa., did not constitute a taking (public health regulation); Supreme Court affirmed

First Evangelical

Lutheran Church v.

County of

Los Angeles

482 U.S. 304 (1987)

Nollan v. California Coastal Commission 483 U.S. 835 (1987)
County barred construction in flood-prone area; church claimed ordinance denied use of its property; Cal. S. Ct. struck down claim for damages; Cal. Ct. App. affirmed; Supreme Court reversed and remanded

Commission conditioned permit sought by owners of beachfront lot on their granting public easement across their land; claimed this was in violation of 5 th Amendment; Cal. Ct. App. held coastal commission could condition permit on easement; Supreme Court reversed and held it required just compensation

Powell, joined by Brennan, joined by Burger

Brennan, Marshall, Marshall Stewart, joined by

Blackmun Stevens Rehnquist, White

Brennan, joined

by Stewart, White

Marshall, Blackmun,

Powell

Rehnquist, joined

by Burger, Stewart,

White, Powell

Stevens
Rehnquist, joined by Burger and Stevens

Blackmun, joined by Brennan and Marshall

Powell (unanimous)

Blackmun, joined by Burger, White Rehnquist, Stevens
Rehnquist

Brennan, joined by

Powell
Marshall, joined

by Burger, Powel,

Rehnquist, Stevens,

O'Connor

O'Connor, joined

by Burger, Brennan,

White, Blackmun,

Powell, Rehnquist,

Stevens
Blackmun, joined by Burger, Brennan, Marshall, Rehnquist, O'Connor
Brennan, joined by

Marshall

Stevens
Blackmun, joined by Brennan and White

$\begin{array}{ll} & \text { White, joined by } \\ \text { Stevens, joined by } & \text { Burger and Powell, } \\ \text { Brennan, Marshall, } & \text { and Rehnquist } \\ \text { Blackmun, } & \text { joined in part } \\ \text { O'Connor } & \text { Rehnquist, joined } \\ & \text { by Powell }\end{array}$

Stevens, joined by

Brennan, White, Marshall, Blackmun
Rehnquist,

joined by Powell,

O'Connor, Scalia
Rehnquist, joined

by Brennan, White,

Marshall, Powell, Scalia
Stevens, joined in part by Blackmun and O'Connor
Scalia, joined by

Rehnquist, White,

Powell, O'Connor
Brennan, joined by Marshall

Blackmun

Stevens, joined by Blackmun 


\section{Yee v. City of}

Escondido

503 U.S. 519 (1992)

Lucas v. South
Carolina Coastal
Council
505 U.S. 1003
(1992)

Dolan $v$. City of
Tigard
512 U.S. 374 (1994)

..........................

City mobile home rent control ordinance challenged-petitioners claimed it amounted to physical taking; Cal. trial and appellate cts. held ordinance did not constitute a taking; Supreme Court affirmed
O'Connor, joined by

$\begin{array}{ll}\text { Rehnquist, White, } & \text { Blackmun } \\ \text { Stevens, Scalia, } & \text { Souter }\end{array}$

Kennedy, Thomas
Beachfront Management Act prevented Lucas from building on his lots (owned prior to enactment of statute); trial ct. held land valueless; S.C. Sup. Ct. reversed and held no taking occurred; Supreme Court reversed and remanded
Scalia, joined by

Rehnquis,, White,

O'Connor, Thomas
Blackmun

Stevens

Souter (cert improperly granted)
City conditioned Dolan's permit on dedicating property for a floodway and public bike path; Dolan claimed this was a taking; Or. Supreme Court held conditions reasonable; Supreme Court reversedcity did not establish conditions were proportionate to impact of development
Suitum v. Tahoe Regional Planning Agency 520 U.S. 725 (1997)

TRPA determined Suitum's land was ineligible for development, but denied relief; Suitum claimed a taking; lower ct determined petition not ripe; Supreme Court vacated lower ct. determinations and held that case was ripe because TRPA had made final determination

Developer claimed unlawful deprivation of property after rejection of development plan for beachfront property; jury found for City of Monterey $v$ Del Monte Dunes 526 U.S. 687 (1999) developer; appellate cr. affirmed; Supreme Court affirmed-deprivation of use of property was up to jury to determine

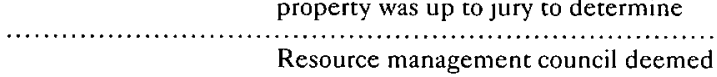

Palaziolo v. Rhode Island Palazollo's land protected coastal wetland and eventual application to fill property 533 U.S. 606 (2001) was denied; state ct. rejected takings claim; Supreme Court affirmed in part and reversed in part, remanded for further proceedings Agency imposed temporary moratoria on

Tahoe-Sierra Preservation Council v. Tahoe RPA 535 U.S. 302 (2002) development of lakefront; landowners claimed deprivation of all viable economic use; district ct. held taking occurred; ct. app. reversed; Supreme Court affirmed app. ct.-no taking occurred, finding taking in every temporary situation would be unreasonable

Chevron claimed cap on rent for companyowned service stations was unconstitutional taking; District ct. held rent cap was in

Lingle v. Chevron 544 U.S. 528 (2005) affirmed; Supreme Court reversed

Rehnquist, joined by O'Connor, Scalia,

Kennedy, Thomas
Stevens, joined by Blackmun and Ginsburg Souter
Souter (unanimous
Scalia, joined in pertinent part)
O'Connor

\begin{tabular}{|c|c|c|}
\hline $\begin{array}{l}\text { Kennedy, joined by } \\
\text { Rehnquist, Stevens, } \\
\text { Scalia, Thomas }\end{array}$ & $\begin{array}{l}\text { Souter, joined by } \\
\text { O'Connor, Ginsburg, } \\
\text { Breyer (concurring } \\
\text { in part and } \\
\text { dissenting in part) }\end{array}$ & \\
\hline $\begin{array}{l}\text { Kennedy, joined } \\
\text { by Rehnquist, } \\
\text { O'Connor, Scalia, } \\
\text { Thomas and in part } \\
\text { by Stevens }\end{array}$ & $\begin{array}{l}\text { O'Connor } \\
\text { Scalia } \\
\text { Stevens }\end{array}$ & $\begin{array}{l}\text { Ginsburg, joined by } \\
\text { Souter and Breyer } \\
\text { Breyer }\end{array}$ \\
\hline $\begin{array}{l}\text { Stevens, joined by } \\
\text { O'Connor, Kennedy, } \\
\text { Souter, Ginsburg, } \\
\text { Breyer }\end{array}$ & & $\begin{array}{l}\text { Rehnquist, joined } \\
\text { by Scalia and } \\
\text { Thomas } \\
\text { Thomas, joined by } \\
\text { Scalia }\end{array}$ \\
\hline
\end{tabular}

Scalia

Souter, joined by

O'Connor, Ginsburg

Breyer (concurring

in part and dissenting in part)

O'Connor Kennedy

(unanimous) $\begin{array}{ll}\text { San Remo Hotel } v . & \text { Hotel owners sued claiming that ordinance } \\ \text { City/County of San } & \text { requiring in lieu fee to convert to tourist }\end{array}$ Francisco

545 U.S. 323 (2005)

Kelo v. City of New London 545 U.S. 469 (2005)

\section{Stop the Beach} Renourishment v. Florida Dep't of Environmental Protection 130 S.Ct. 2592 (2010) hotel was a taking; state court rejected claim; U.S. Ct. app. rejected takings claims; Supreme Court affirmed law; Supreme Court unanimously found there
City initiated condemnation proceedings on nine properties; trial court prohibited taking; Conn. Supreme Court reversed and upheld takings; Supreme Court affirmed Conn. Supreme Court-economic development constituted public use

Beachfront property owners brought facial takings challenge to Act providing for beach restoration, claiming it had the effect of taking certain property rights; Fla. Supreme Court ruled there was no taking under state property was no taking under background principles of Florida property law, but four justices argued there could be a "judicial taking" of property Stevens did not participate (owns beachfront property in Florida)
Stevens, joined by Scalia, Souter, Ginsburg, Breyer
Rehnquist, joined by O'Connor,
Kennedy, Thomas
Stevens, joined by Kennedy, Souter, Ginsburg, Breyer
O'Connor, joined by Kennedy Rehnquist, Scalia, Thomas Thomas
Scalia (unanimous in part) and joined by Roberts, Thomas, Alito in part
Kennedy, joined by Sotomayor

Breyer, joined by Ginsburg 
question in First English, but his would become the majority view 15 years later in Tahoe-Sierra when the question of whether compensation was also constitutionally mandated for "normal delays" came before the Court.

interest affected in Keystone as only the coal that would have to be left in place to avoid subsidence, rather than defining the property interest as the entire coal deposit.

The segmentation issue was not new. In Pennsylvania Coal, Justices Holmes and Brandeis had disagreed on this point, with Holmes defining the property interest affected as the coal left in place and Brandeis as the entire coal mining enterprise. The issue had also been a factor in Penn Central, where the plaintiff's claim that its "air rights"-the right to develop the space above the existing terminal-were a separate property interest that had been taken when the Landmarks Commission denied it permission to build an office tower above the terminal. In 1978, Justice Stevens had joined Justice Rehnquist's dissent in Penn Central, finding a taking, in part because the "air rights" above the terminal were a recognizable property interest. ${ }^{39}$ By 1987 , his views had changed.

Justice Stevens was a dissenter in the other two cases decided in 1987, First English ${ }^{40}$ and Nollan ${ }^{41}$ First English, a 6-3 decision, at last resolved the compensatory question. Rehnquist's opinion held that the Just Compensation Clause of the Fifth Amendment allowed a property owner to recover damages when a land use regulation affects a "temporary taking" of property. Stevens's dissent, joined by Blackmun and O'Connor as to the first and third of the following points, argued: (1) The Court should have found that the county ordinance at issue, which prohibited permanent structures in an area prone to flash floods that had recently claimed several lives, was not a taking; (2) the majority was wrong in ruling that compensation is the appropriate remedy for a "temporary taking"; (3) the Court should have required the plaintiff to exhaust his state remedies before hearing the case; and (4) it is the Due Process Clause, rather than the Just Compensation Clause, that protects property owners from improper, unfair, or unnecessarily protracted governmental decision making.

Here again we see the importance Justice Stevens placed on the temporal element. His dissent argued that "[r] egulations are three dimensional: They have depth, width and length." He explained that depth refers to the restrictions placed on the property, width refers to the amount of property burdened by the restrictions, and length refers to the duration of the restrictions. ${ }^{42} \mathrm{He}$ then argued: "Just as it would be senseless to ignore these first two factors in assessing the economic effect of a regulation, one cannot conduct the inquiry without considering the duration of the restriction." ${ }^{43}$ Finally, he noted that the majority had excluded "normal delays in obtaining building permits, changes in zoning ordinances, variances and the like" 44 from its compensation rule and argued this was an artificial distinction based on the logic of the majority's reasoning. Stevens was alone regarding the importance of the temporal question in First English, but his would become the majority view 15 years later in Tahoe-Sierra when the question of whether compensation was also constitutionally mandated for "normal delays" came before the Court.

The last of the 1987 cases, Nollan, was significant in three respects: (1) It was the first Supreme Court case since Pennsylvania Coal holding that a land use regulation violated the takings clause, ${ }^{45}$ (2) Justice Scalia's majority opinion was his first on the takings issue, and (3) the case was the first in which the Court analyzed land use exactions under the takings clause. Scalia held that a land use exaction was valid only if there was an "essential nexus" between the condition imposed on the property and the regulatory purpose for the condition; here, a requirement that the Nollans dedicate a lateral easement for public access across their beachfront property as a condition for obtaining a permit to build a larger house. The Coastal Commission had claimed the easement was required to reduce obstacles to the public's viewing the beach, lower psychological obstacles to public use of the beach, and reduce beach congestion caused by the construction of the Nollans' house. Scalia argued that requiring the dedication of an easement, a recognized property interest, appropriately subjected the dedication requirement to heightened scrutiny and the commission had not sustained its burden of demonstrating that the condition it imposed substantially advanced the interests it had cited to justify the requirement. In short, the commission could obtain an easement from the Nollans only through purchase or condemnation and payment of just compensation.

There were three separate dissents, authored by Justices Brennan, Blackmun, and Stevens, with four justices dissenting in total. It is intriguing to speculate whether the dissenters' views, in fact, might have garnered a majority at some point in the Court's deliberations, since much of Justice Scalia's argument refutes Brennan's views in a manner more reminiscent of a dissent than a majority opinion.

Justice Brennan's lengthy dissent, joined by Justice Marshall, argued that the majority had improperly subjected the dedication requirement to heightened scrutiny and, even though that standard was not required, the easement requirement could meet it. Interestingly, these two justices had been part of the majority in First English. Justice Blackmun's much shorter dissent agreed with Brennan that heightened scrutiny was not required and noted that Justice Scalia's opinion did not implicate the public-trust doctrine. Justice Stevens's dissent, joined by Blackmun, his fellow dissenter in First English, was essentially an "I told you so" taking Brennan to task for his San Diego Gas dissent arguing a compensation remedy was required for a temporary taking and for joining the majority adopting that rule in First English. ${ }^{46}$ Stevens noted that although "[e]ven the wisest lawyers would have to acknowledge great uncertainty about the scope of the Court's takings jurisprudence," First English made local government pay a price for honestly misjudging the law in this uncertain area ${ }^{47} \mathrm{He}$ then softened that criticism, presumably in the hope of garnering Brennan's vote in a future takings case, by praising Brennan for recognizing that government needed some flexibility in mediating between 
the desires of private developers and the preservation of public resources, and implicitly encouraging him to recognize that his support for the compensation remedy may have been mistaken.

\section{JUSTICE STEVENS AND THE PROPERTY RIGHTS COURT}

It would be five years, however, before the Court heard Lucas v. South Carolina Coastal Council, ${ }^{48}$ its next land use takings case. In the meantime, Justice Brennan had retired in 1990 and the first President Bush appointed David Souter, a little-known state appeals court judge from New Hampshire to fill his seat. There were two other changes on the Court over that five-year period. President Reagan had appointed Anthony Kennedy to replace Justice Powell in 1988 and Bush appointed Clarence Thomas to replace Justice Marshall in 1991. In each of these cases, as well as the appointment of Justice O'Connor to replace Justice Stewart in 1981, the new Justice was more conservative than his or her predecessor. The Thomas appointment was particularly critical. Marshall had been favorable to Stevens's view of the takings clause in Keystone and Nollan; Thomas clearly would favor Scalia's view. As a result, the 1992 Court that considered Lucas was markedly more conservative than the 1987 Court which had decided the "takings trilogy."

In Lucas, Justice Scalia, joined by Justices Rehnquist, White, O'Connor, and Thomas, announced the Court's second "categorical" taking rule: A regulation that denied all economically viable use of property was a taking without regard to the purported governmental interest served unless the restriction imposed by the regulation either inhered in the title to the property or could have been achieved under the state's common law of property. Applying this rule, Scalia found that the South Carolina coastal management statute had prohibited David Lucas from developing his two beachfront lots and thus was an unlawful taking of his property. Scalia noted that the legislature could not lawfully deny all use even if the stated purpose of its regulation was to prevent a harm, includ- ing preventing a "noxious use" of private property. "Any limitation so severe cannot be newly legislated or decreed (without compensation) but must inhere in the title itself, in the restrictions that background principles of the State's law of property and nuisance already place upon land ownership, he wrote. ${ }^{49}$

Justice Kennedy concurred in the judgment, but wrote separately to disagree with Justice Scalia's view that a state could not enact new regulatory initiatives that would impose severe restrictions on property without having to pay compensation to the affected property owners, arguing that " $[\mathrm{t}] \mathrm{he}$ common law of nuisance is too narrow a confine for the exercise of regulatory power in a complex and interdependent society." As we will see, Kennedy's concurring opinion in Lucas was a signal that Justice Scalia apparently chose to overlook but Stevens did not.

Justice Blackmun wrote a stinging dissent in Lucas that famously began, "Today the Court launches a missile to kill a mouse." 51

Justice Stevens's dissent disagreed with Justice Scalia's new categorical rule on a number of grounds. For one, he thought it was arbitrary, noting that a regulation that reduced property values by 95 percent would now be treated very differently from one that reduced property value by 100 percent. The rule also implicated his concerns with the segmentation issue: "... developers and investors may market specialized estates to take advantage of the Court's new rule. The smaller the estate, the more likely that a regulatory change will effect a total taking." $52 \mathrm{He}$ also saw the "denial of all use" standard as concerned too much with the effect of the regulation and not enough with the reason for the regulation. Here, because the challenged statute affected all coastal property owners in an effort to prevent serious harm, Stevens did not view the law as "singling out" any particular property owner to bear an unfair burden and thus the law was not a taking. Stevens analogized the effect of the statute to the Court's First Amendment cases, and in particular Scalia's recent and controversial opinion in Smith, which upheld neutral laws of general applicability even when they imposed a substantial burden on the free exercise of religion. ${ }^{53}$ Stevens argued: "[If] such a neutral law of general applicability may severely burden constitutionally protected interests in liberty, a comparable burden on property owners should not be considered unreasonably onerous." 54

Justice Scalia continued to press his property rights agenda over the following decade, but arguably was not as successful as he might have hoped. In the Court's next takings case, Dolan v. City of Tigard, ${ }^{55}$ an exactions case like $\mathrm{Nol}$ lan, Chief Justice Rehnquist's majority opinion was joined by Justices O'Connor, Scalia, Kennedy, and Thomas. Rehnquist had no trouble agreeing that the exaction here satisfied Nollan's essential nexus requirement. As a result, the Court now had to decide "whether the degree of the exactions demanded by the city's permit conditions bears the required relationship to the projected impact of petitioner's proposed development," a question the Court had not reached in Nollan because that exaction had failed the essential nexus test. After acknowledging that the various state courts which had addressed this issue had crafted standards ranging from lax to exacting, the Court adopted a "rough proportionality" test $\mathrm{t}^{56}$ similar to the "reasonable relationship" test used by the majority of states. Applying that test, the Court ruled that the city had not met its burden of proof with regard to the exactions it had demanded and remanded the case to give the city an opportunity to meet the Court's just announced test. ${ }^{57}$

Justice Stevens dissented, joined by Justices Blackmun and Ruth Bader Ginsburg, who had been appointed to fill the seat vacated when Justice White retired in 1993. Stevens's dissent echoes what should now be familiar themes in his view of the takings clause, concerns about the segmentation issue and the need for the Court to give government adequate leeway in mediating between private and public interests. As regards segmentation, Stevens criticized the Court's preoccupation with the segment of the property subject to the exaction rather than looking to the entire property, and particularly the question of 
whether the required dedication might benefit the property owner to some extent. On the second point, Stevens argued that the majority was wrong to place the burden on government to justify its dedication by meeting the new "rough proportionality" test, arguing: "[T] $]$ he burden of demonstrating that those conditions have unreasonably impaired the economic value of the proposed improvement belongs squarely on the shoulders of the party challenging the state action's constitutionality. That allocation of burdens has served us well in the past. The Court has stumbled badly today by reversing it." ${ }^{8}$ Justice Souter's separate dissent essentially agreed with Stevens on this point. ${ }^{59}$

Dolan was Justice Blackmun's last land use case. He retired in the summer of 1994 and was replaced by Justice Stephen Breyer. The membership of the Court would then remain stable for 11 years, the second longest period without a change in composition in the Court's history. This Court could easily be seen as divided into three groups: Justices Rehnquist, Scalia, and Thomas were avowedly conservative; Justices Stevens, Ginsburg, Breyer, and increasingly Souter, were liberal; and Justices O'Connor and Kennedy were somewhere in between. The Court's subsequent takings cases would now largely be decided on the basis of whether Scalia or Stevens could gain the support of one, or both, of the justices in the middle.

But the Court's next three takings cases, Suitum v. Tahoe Regional Planning Agency ${ }^{60}$ in 1997, City of Monterey v. Del Monte Dunes ${ }^{61}$ in 1999, and Palazzolo v. Rhode Island $d^{62}$ in 2001, failed to pit Stevens and Scalia as rivals seeking to attract four other justices to his view. In Suitum, Justice Souter announced the Court's unanimous judgment reversing a Ninth Circuit ruling that a takings claim was not ripe and remanded the matter. Justice Scalia's concurrence, joined by Justices Thomas and O'Connor, argued that Souter's opinion should not have discussed the availability and potential value of Transferable Development Rights (TDRs) as relevant to the issue of whether there had been a taking, because the availability of TDRs properly goes to the question of whether there has been just compensation after a taking is found.

In Del Monte Dunes, Justice Stevens parted company with the liberal justices and joined Justice Kennedy's majority opinion, along with Justices Rehnquist, Scalia, and Thomas, upholding a jury verdict finding a taking and awarding compensation. The facts in this case showed that the city had, over a five-year period, denied approval for development five separate times, each time suggesting that if the developer would only address the city's concerns, all would be well when the developer reapplied. After 19 separate site plans had been rejected because the city's concerns were continually shifting, the developer sued. These facts, showing government unfairly burdening a specific land owner are, of course, the key to Stevens's vote. From the standpoint of takings jurisprudence, however, the most important ruling in Del Monte Dunes was the rejection by all the Justices of the Ninth Circuit's ruling that Dolan's "rough proportionality" standard should be applied to all takings claims based on the "fails to substantially advance" prong of Agins in takings cases, rather than limited to claims involving exactions.

In Palazzollo, Justice Scalia's adversary was Justice O'Connor, not Justice Stevens. The Court was unusually fractured here, producing six separate opinions. Justice Kennedy's majority opinion was joined by Justices Rehnquist, O'Connor, Scalia, Thomas, and in part, by Stevens. But Stevens also wrote separately, concurring in part and dissenting in part. O'Connor and Scalia wrote concurring opinions, each taking the other to task, albeit O'Connor doing so less harshly than Scalia. Justice Ginsburg's dissent was joined by Justices Souter and Breyer, who also dissented separately. The most critical issue before the Court here was the "notice" rule, which held that a land owner who had notice of a regulation at the time he acquired the property was barred from bringing a takings claim based on that regulation. The majority rejected the "notice" rule, but Scalia and O'Connor bickered over what role having preacquisition notice of a regulation should play in determining an owner's "reasonable investment-backed expectations" as part of a Penn Central analysis. O'Connor argued that because "[t]he regulatory regime in place at the time the claimant acquires the property at issue helps to shape the reasonableness of those expectations," ${ }^{63}$ it must be considered. In his concurrence, Scalia took direct aim at Justice O'Connor: "I write separately to make clear that my understanding of how the issues discussed in ... the Court's opinion must be considered on remand is not Justice O'Connor's." ${ }^{\prime 4} \mathrm{He}$ argued that notice should play no role in a Penn Central takings analysis because doing otherwise would only allow the government to benefit from its own misdeed in enacting the unconstitutional regulation in the first place. ${ }^{65}$

Stevens's separate opinion showed that the temporal element remained critical in his view of the takings clause. Arguing that "[p]recise specification of the moment a taking occurred and of the nature of the property interest taken is necessary in order to determine an appropriately compensatory remedy," 66 he concluded that either the claimant here was not the proper party to bring the claim, because the taking occurred before he owned the property, or "if the only viable takings claim has a different predicate that arose later, that claim is not ripe." ${ }^{67}$

AND THE WINNER IS . . . JUSTICE STEVENS Between 2002 and 2005, the Court ruled on three land use takings cases: TahoeSierra, San Remo, and Kelo. A fourth case, Lingle, although not itself a land use case, overruled a previous land use takings case, Agins. Justice Stevens was in the majority in each of these and authored all of the opinions except Lingle. Although Justice Scalia did not dissent from the Court's unanimous opinion in Lingle, and joined Stevens's majority opinion in San Remo, he was in the minority in Tahoe-Sierra and Kelo, the two cases where the "property rights" view of the takings clause was really at issue. It was clear that the Court's acceptance of that view of the takings clause over the past 15 years, as could be seen from the majorities which favored the com- 
pensatory remedy in First English, the heightened standard of review for exactions in Nollan and Dolan, the categorical "denial of all use" takings rule in Lucas, the approval of the jury's award of damages for a taking in Del Monte Dunes, and the invalidation of the "notice" rule as a bar to takings claims in Palazzollohad come to an end.

The Tahoe-Sierra $a^{68}$ case involved a challenge by almost 500 property owners to a series of moratoria halting development for 32 months while the Tahoe Regional Planning Agency (TRPA) prepared a new regional plan to protect Lake Tahoe from degradation of its famously clear water due to the effects of new development, such as increased stormwater runoff from impervious surfaces. The property owners had won at the federal district court. That lower court, after deciding that the moratoria were not a temporary taking under Penn Centrals balancing test, ruled that they were a categorical "denial of all economically viable use" taking under Lucas during the 32 months of the moratoria, and ordered TRPA to pay damages to the property owners. ${ }^{69}$

Both TRPA and the property owners appealed. TRPA appealed the district court's finding of a taking and the property owners appealed the district court's ruling that the total time period for the moratoria was 32 months, rather than a longer period for which they had argued. The property owners did not appeal the district court's denial of their Penn Central temporary takings claim. The Ninth Circuit ruled against the property owners and for TRPA, holding that the temporary takings doctrine announced in First English does not apply to temporary development moratoria because a temporary taking should not be considered a denial of all economically viable use under Lucas. $^{70}$

Justice Stevens's opinion, joined by both Justices O'Connor and Kennedy in addition to Justices Souter, Ginsburg, and Breyer, involved all three of the issues that shaped his view of the takings clause: the potential for manipulation of outcomes due to segmentation of property interests; a concern for the temporal aspect of a regulation; and deference to general government regulations that sought to achieve legitimate public purposes. Here, his first two concerns were merged, since the plaintiffs' Lucas claim rested on a temporal segmentation of their property interest: the 32-month period during which they argued they could make no economically viable use of their property. Stevens essentially argued that temporal segmentation could no more be a valid basis for finding a taking than would segmentation of just the portion of a property that could not be "used" due to a regulation, while the rest of the property was not so burdened or focusing just on the uses for a property that a regulation prohibited when other economically viable uses were allowed. In this view, Lucas's requirement of a denial of all economically viable use would not be satisfied by looking only at the period a moratorium was in effect, since the property affected by the moratorium would regain its value as soon as the moratorium was lifted.

Regarding the third element in Justice Stevens's view of the takings clause-support for general regulations that advance legitimate state interestshe first noted that "with a temporary ban on development there is a lesser risk that individual landowners will be 'singled out' to bear a special burden that should be shared by the public as a whole." The reason for the moratorium-ensuring the continued protection of Lake Tahoe-would provide a benefit in return for the burden of the moratorium, thus effectively providing an "average reciprocity of advantage."

Viewed more broadly, Stevens's opinion was a major blow to the "property rights" position. He garnered a majority of the Court to support his arguments that: (1) The First English temporary taking rule was not applicable when property could not be used for a period of time due to normal delays in the land use process, including moratoria, although noting that "[i]t may well be true that any moratorium that lasts for more than one year should be viewed with special skepticism"; 71 and (2) because the Lucas categorical taking rule applies only in "the 'extraordinary case' in which a regulation permanently deprives property of all value; the default rule remains that, in the regulatory taking context, we require a more fact specific inquiry," or, in other words, Penn Central is the "default" takings rule. ${ }^{72}$

Chief Justice Rehnquist's dissent, arguing that while "normal delays" should not be viewed as a temporary taking, a moratorium of this length should, attracted only Justices Scalia and Thomas, the Court's most conservative justices. Thomas, joined only by Scalia, also dissented, effectively arguing that any delay that denied all use was a taking, with the length of the delay relevant only to the question of damages.

Justice Stevens perhaps relied on more than just the force of his arguments to craft a six-member majority: His opinion incorporates major portions of both Justice Kennedy's majority opinion and Justice O'Connor's concurrence in Palazollo. One has to believe that quoting at length in your opinion from justices whose votes you are seeking to retain is not a mere coincidence, but rather an effective strategy.

In 2005, the Court ruled on three more takings cases: Lingle, San Remo, and Kelo. Lingle, in which the Court overturned the "fails to substantially advance" prong of Agins, and in the process greatly clarified takings doctrine, and San Remo, where the Court held that the federal full faith and credit statute precluded further litigation in federal court of issues that had been resolved in a state court proceeding, were both decided unanimously. Kelo, in contrast, was a $5-4$ decision that featured an uncharacteristically strident dissent by Justice O'Connor.

Lingle clarified takings doctrine in two aspects. First, Justice O'Connor's opinion argued that what unifies the Court's two categorical takings testsdenial of all economically viable use (Lucas) and physical invasion/occupation (Loretto) - and the Penn Central balancing test, is that each seeks to identify whether a regulation is the functional equivalent of a "classic taking in which government directly appropriates private property or ousts the owner from his domain." In other words, the unifying factor among these tests is their direct focus "upon the severity of the burden that government imposes upon 
private property rights." 73 In contrast, O'Connor argued, the Agins "substantially advances" test "prescribes an inquiry in the nature of due process, not a takings test, and ... [thus] has no proper place in our takings jurisprudence." 74

The fatal flaw in this approach is that "in stark contrast to the three regulatory takings tests discussed above, the 'substantially advances' inquiry reveals nothing about the magnitude or character of the burden a particular regulation imposes upon private property rights. Nor does it provide any information about how any regulatory burden is distributed among property owners. In consequence, this test does not help to identify those regulations whose effects are functionally comparable to government appropriation or invasion of private property; it is tethered neither to the text of the Takings Clause nor to the basic justification for allowing regulatory actions to be challenged under the Clause." 75 Thus, the "substantially advances" prong of Agins would no longer be good law. Justice O'Connor then clarified that while both Nollan and Dolan had cited Agins" "substantially advances" language, the rule in those exactions cases is not affected by the rejection of the substantially advances test as a general takings inquiry. ${ }^{76}$ Justice Kennedy added a brief concurring opinion noting that the decision "did not foreclose the possibility that a regulation might be so arbitrary or irrational as to violate due process."77

One can see the influence of Justice Stevens's view of the takings clause in Justice O'Connor's opinion. Her emphasis on the failure of the "substantially advances" test to address the distributional effects of a regulation reflects Stevens's concern about whether the burden of a regulation is shared generally as opposed to being imposed on only a few.

Justice Stevens wrote the opinion for a unanimous Court in San Remo Hotel, L.P. v. City and County of San Francisco, ${ }^{78}$ a procedural decision that I will discuss only briefly. The Court took San Remo to resolve a split between the Second and Ninth Circuits regarding whether a plaintiff, who had been forced to seek compensation for a taking in state court as mandated by Williamson County, could then litigate that same takings claim in federal court. The Second Circuit had ruled that parties "who litigate state-law takings claims in state court involuntarily" pursuant to Williamson County cannot be precluded from having those same claims resolved in federal court. ${ }^{79}$ The Ninth Circuit, in San Remo, disagreed, holding that the federal full faith and credit statute requires federal courts to give preclusive effect to any state-court judgment that would have preclusive effect under the laws of the state in which the judgment was rendered. Stevens's opinion agreed with the Ninth Circuit's position. Chief Justice Rehnquist's concurring opinion, joined by Justices O'Connor, Kennedy, and Thomas, agreed that the full faith and credit statute precluded plaintiffs from relitigating a takings claim in federal court, but he also questioned whether Williamson County's requirement that a takings claimant must first seek compensation in state court should be retained.

Of the Court's three takings decisions in 2005, Justice Stevens's majority opinion in Kelo v. City of New London ${ }^{80}$ by far received the most attention. In a very real sense, this had less to do with Stevens's opinion than with the uncharacteristically strident dissent authored by Justice O'Connor. Stevens's opinion held that the city's exercise of its eminent domain power solely to achieve economic development goals satisfied the "public use" requirement of the takings clause. The mere fact that O'Connor dissented in Kelo was a surprise, given that she had authored the majority opinion in Midkiff holding that the power of eminent domain was coextensive with the police power, but the tone of her dissent was a shock. Although long seen as a moderate occupying a centrist position on the Court, in Kelo, O'Connor not only voted with Justices Rehnquist, Scalia, and Thomas, the most conservative members of the Court, but authored a dissent that rivals any by Scalia in rhetorical effect.

Justice Stevens's carefully argued majority opinion stressed the various factors a court must examine to determine whether the use of eminent domain for economic development is truly serving a legitimate public purpose, rather than improperly promoting purely a private benefit. Most important was whether a city was acquiring the property within "the confines of an integrated development plan" that was adopted and implemented by means of a thorough and deliberative process. ${ }^{81}$

But Justice O'Connor's dissent insisted that the majority's ruling made nearly all private property "susceptible to condemnation on the Court's theory." 82 Hammering the point home, she declared: "The specter of condemnation hangs over all property. Nothing is to prevent the State from replacing any Motel 6 with a Ritz-Carlton, any home with a shopping mall, or any farm with a factory." 83 O'Connor's inflamed rhetoric was immediately picked up and widely disseminated by advocates for the so called property-rights movement, as well as the media, perhaps because capitalizing on the hyperbole of "replacing any Motel 6 with a Ritz-Carlton" proved irresistible when compared with the parsed tone of Justice Stevens's opinion.

\section{THE FUTURE?}

Justice Stevens remained on the Court for five more terms, but Kelo would be his last opportunity to present his views on the takings clause in a land use case. Although the Court decided a takings case implicating land use regulation in June $2010,{ }^{84}$ Stevens did not participate because he owns beachfront property in Florida that could be affected by the Court's ruling. Even though Stevens recused himself, Stop the Beach Renourishment is worth examining briefly for the hints it provides as to the Court's direction in future takings cases with Stevens no longer on the bench.

In Stop the Beach Renourishment, the Court considered a facial takings challenge to Florida's Beach and Shore Preservation Act brought by certain owners of beachfront property. The Act provides for the restoration and "renourishment" of storm-eroded beaches; the basis for the property owners' claim was the effect beach restoration would have on defining their property lines, and particularly whether their private property would continue to extend 
to the water's edge. The Florida Supreme Court had ruled that under state property law, when the state restores a beach by adding sand to land that had previously been under water, the newly added portion of the beach belongs to the state and not the abutting property owner.

That ruling had two significant effects on the rights of the beachfront property owners: first, their property no longer extended to the water's edge, meaning portions of the now-restored dry sand beach in front of their homes were open to the public; and second, they could no longer claim accretions to the beach-the gradual and imperceptible expansion of the beach due to waves depositing sand on the shore-as extending their private property.

The Court was unanimous in finding that background principles of Florida state property law supported the state's position and thus there had been no taking. But the Court was evenly split on the question of whether there could be such a thing as a "judicial taking" of property. Justice Scalia, joined by Chief Justice Roberts and Justices Thomas and Alito, concluded that if a court declares that what was once an established right of private property no longer exists, it has taken that property in violation of the takings clause. Justice Kennedy, joined by Justices Sotomayor, Breyer, and Ginsburg, while agreeing with Scalia that there had been no taking, declined to join the portion of Scalia's opinion that claimed the judicial branch could effect a taking, arguing that this case did not require the Court to decide that question.

What is most interesting about this case is that Justice Kennedy, the sole remaining "swing vote" on the Court, voted with the Court's liberals, rather than its conservatives, on the judicial taking question and thus declined again to ally himself with Justice Scalia's "property rights" view of the takings clause. Kennedy had joined Justice Stevens's majority opinions in Tahoe-Sierra and Kelo, but the composition of the Court had changed . considerably since Kelo in 2005. On July 1, 2005, Justice O'Connor unexpectedly announced her retirement. Two months later, Chief Justice Rehnquist died after battling cancer for several years. President George W. Bush appointed two conservative federal appeals court judges as their replacements: John Roberts as the new chief justice and Samuel Alito to replace O'Connor. Four year later, Justice Souter also resigned unexpectedly and was replaced by Sonia Sotomayor, a liberal Second Circuit judge. Thus, the Stop the Beach Renourishment Court, after Stevens recused himself, comprised four conservative justices (Roberts, Scalia, Thomas, and Alito) and three liberal justices (Breyer, Ginsburg, and Sotomayor), with Kennedy in the middle. It is worth noting that Justice Scalia could not win over Kennedy as the critical fifth vote to establish the concept of a judicial taking.

Justice Stevens departs the Court with his view of the takings clause predominant, rather than Justice Scalia's. The victories for Scalia's view of the takings clause in First English, Lucas, Nollan/ Dolan and, to some extent, in Palazollo, have proved of far less import than was thought at the time these cases were decided. First English established that a compensatory remedy was required for a temporary taking, but the prevalence of Stevens's view opposing segmentation of property interests on either a physical or temporal basis, as seen in Palazollo and Tahoe-Sierra, blocked the expansion of the compensation rule to include "normal delays" in permit approvals and most planning moratoria.

The potential reach of First English was expanded by Palazollo's abolishing the notice rule as a bar to a takings claim, but that expansion was significantly limited because Justice Scalia failed to convince the Court that notice of an existing regulation should play no role in the Penn Central balancing test. Lucas has proved to be of little practical value to takings claimants because regulations that deprive property of all economically viable use are rare, and regulations that do have such an effect may well be grounded in background principles of a state's property law because they target nuisance-like uses of property. Finally, the heightened scrutiny required by Nollan/Dolan has remained narrowly confined to the exactions context.

\section{ENDNOTES}

1. Vill. of Euclid, Ohio v. Ambler Realty Co., 272 U.S. 365 (1926).

2. Nectow v. City of Cambridge, 277 U.S. 183 (1928).

3. Vill. of Beille Terre v. Boraas, 416 U.S. 1 (1974).

4. The other area invotves the land use cases implicating speech and religious rights protected under the First Amendment. Justice Stevens's contribution to First Amendment law is discussed in: Christopher Eisgruber, Justice Stevens, Religious Froodom, and the Value of Equal Membership, 74 Foncham L. Rev. 2177 (2006): Magarian, The Pragmatic Populism of Justice Stevens's Free Speech Jurisprudence, 74 FordwaM L. Rev. 2201 (2006); and Eduardo Moises Penalver, Treating Religlon as Speech: Justice Stevens's Religion Clause Jurisprudence, 74 Fofoham L. Rev, 2241 (2006).

5. See John D. Echeverria, The Trumph of Justice Stevens and the Principte of Generality, in The Supreme Court and Takings: Four Essays, 7 VT. J. Evrt. L. 22 (2006) and Richard J. Lazanus, The Measure of a Justice: Justice Scalia and the Faltering of the Property Rights Movement Within the Supreme Court, 57 Hastings L.J. 759 (2006). See also Richard J. Lazanus, Essay: Celebrating Tahoe-Sierra, 33 EmT. L. 1 (2003) and Marc R. Lisker, Perspectives on Justice John Paul Stevens: Regulatory Takings and the Denominator Problem, 27 RUTGers L.J. 663 , 706-19 (1996).

6. Kelo v. City of New London, 545 U.S. 469 (2005).

7. San Remo Hotel, L.P. v. City and County of San Francisco, 545 U.S. 323 (2005).

8. Penn Central Transp. Co. v. City of N.Y., 438 U.S. 104 (1978). 9. Id. at 147.

10. See Echeverria, supra note 5 at 27-28.

11. This is confirmed in Professor Lazarus's article, which examined Justice Blackmun's notes on the Court's deliberations in Penn Central. That article relates a point Blackmun claims Stevens made duning the Court's conference on Penn Central: "Stevens further described as 'fundamental' the 'distinction between the general and the particular. Zoning is general. Landmarking is not.." Lazarus, supra note 4 at 771.

12. Kaiser Aetna v. United States, 484 U.S. 164 (1979).

13. 1d. at 190 .

14. Loretto v. Teleprompter Manhattan CATV Corp., 458 U.S. 419, 441 (1982).

15. Agins v. City of Tiburon, 447 U.S. 255 (1980).

16. San Diego Gas \& Elec. Co. v. City of San Diego, 450 U.S. 621 (1981).

17. Moore v. City of E. Cleveland, 431 U.S. 494 (1977)

18. Agins, 447 U.S. $255,260-61$ (1980). Interestingly, while the Agins Court announced this new takings test just two years after announcing a different takings test in Penn Central-a "multifactor" balancing test - Justice Powell made no effort to distinguish between them despite the fact that they are clearly different. For example, the Penn Central test looks at diminution of value, not denial of economically viable use, and asks about "the character of the governmental action," rather than whether that action substantially advances legitimate state interests.

19. The Agins "two-part" takings test would be unanimously rejected 25 years later in Lingle v. Chevron, 544 U.S. 528 (2005)

20. In Moore, Justice Stevens split with Burger and Rehnquist. Chief Justice Burger's dissent argued the Court should not have heard the case because Mrs. Moore had not exhausted her administrative remedies. Justice Rehnquist joined Justice Stewart's dissent, which argued the case should have been decided on equal protection, not substantive due process grounds, and the ordinance upheld based on the Court's ruling upholding a restrictive definition of family in Vill. of Belle Terre v. Boraas, 416 U.S. 1 (1974).

21. Moore v. City of E. Cleveland, 431 U.S. 494, 514, citing Euclid v. Ambler Realty Co., 272 U.S. 365 at 395.

22. San Diego Gas \& Elec. Co. v. City of San Diego, 450 U.S. $621,633-34$ (1981).

23. Id. at 653 . 


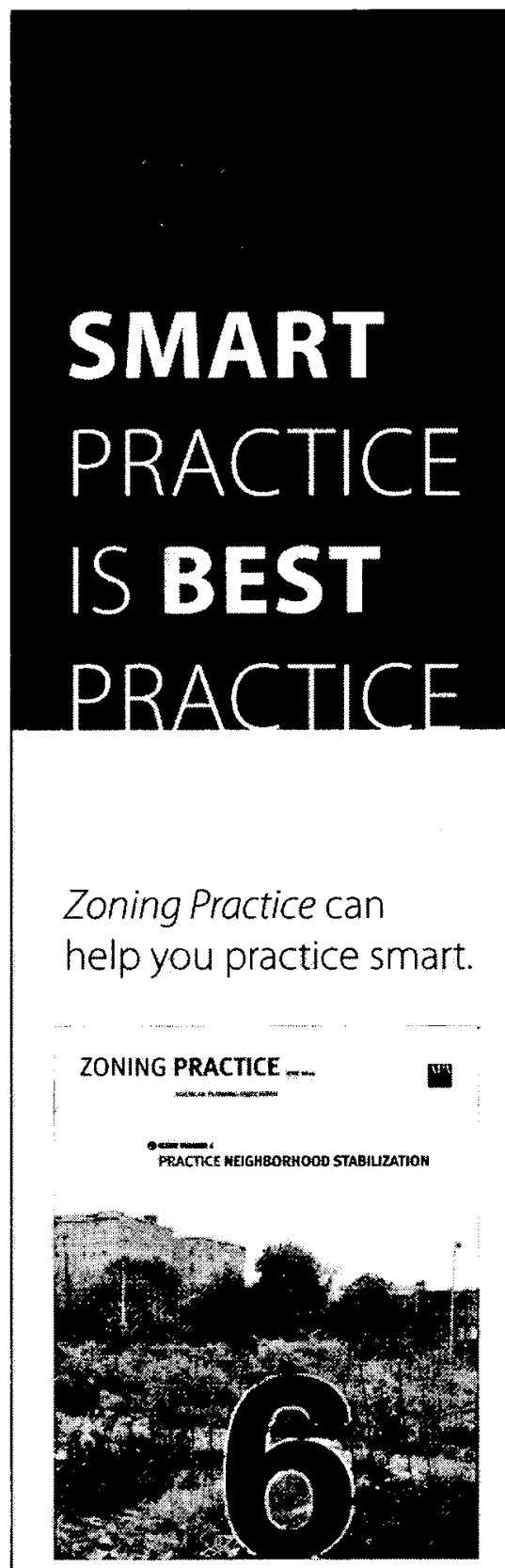

Learn more about $Z P$ and subscribe at www.planning.org/ zoningpractice.
24. First English Evangelical Lutheran Church v. County of Los Angeles, 482 U.S. 304 (1987).

25. Hawail Hous. Auth. v. Midkiff, 467 U.S. 229 (1984).

26. Williamson County Reg'l Planning Comm'n v. Hamilton Bank, 473 U.S. 172 (1985)

27. Agins presented a facial challenge to a zoning ordinance. Based on the "two-part" takings rule it formulated in this case the Court denied the facial takings claim, but declined to rule on the compensatory issue in the absence of a factual record below on the effect of the ordinance as applied to the plaintiffs' property since the plaintiff had never sought development approvel. As noted previously, the Court again faled to reach the compensatory issue in San Diego Gas because there had not been a final decision on whether there was a taking

28. Williamson County, 473 U.S. 172, 204-05 (1985).

29. 1d. at 205.

30. McDonald, Sommer \& Frates v. Yolo County, 477 U. $\$ .340$ (1986).

31. Id. at 351.

32. ld. at $352 \mathrm{fn} .8$.

33. 482 U.S. 304 (1987)

34. Lazarus, supra note 5 at 783 makes this point: "Soon after Justice Scalia joined the Supreme Court in 1986, he quickly became the property rights movement's strongest ally on the bench. During his very first Term, he voted in favor of greater protection of property owners in all four of the significant property rights cases before the Court that Term."

35. See, generally, Lazarus, supra note 5.

36. Keystone Bituminous Coal Ass'n v. DeBenedictis, 480 U.S. 470 (1987).

37. Pa. Coal Co. v. Mahon, 260 U.S. 393 (1922).

38. Keystone Bituminous Coal Ass'n v. DeBenedictis, 480 U.S. 470, 491 (1987).

39. Penn Central, 438 U.S. 104,143 fn. 5 (1978).

40. First English Evangelical Lutheran Church v. County of Los Angeles, 482 U.S. 304 (1987)

41. Nollan v. Cal. Coastal Comm'n, 483 U.S. 825 (1987).

42. First English Evangelical Lutheran Church v. County of Los Angeles, 482 U.S. 304,330 (1987)

43. 1d, citing Williams, Smith, Siemon, Mandelker \& Babcock, The White River Junction Manifesto, 9 VT. L. Rev. 193, 215-218 (1984), authored by the leading land use planning attorneys and scholars of the time, one of whom. Professor Daniel Mandelker, remains a leading figure to this day.

44. 1d. at 321.

45. The decision in First English had been limited to the compensation issue and the case was remanded to the California state courts, which ruled that the chalienged ordinance was not a taking in light of the significant risk of injury to property and life posed by flooding.

46. Brennan chose not to respond to Stevens's criticism of him in Nollan.

47. Noilan v. Cal. Coastal Comm'n, 483 U.S. 825, 866 (1987). 48. Lucas v. S.C. Coastal Council, 505 U.S. 1003 (1992). That same year, the Court also ruled in Yee v. City of Escondido, 503 U.S. 519 (2002), that a local rent control ordinance was not a physical taking. Justice $O^{\prime} C o n n o r$ authored the majority opinion, which was joined by six justices from both sides of the takings debate.

49. 10. at 1029

50. 1d. at 1036

51. 1d. Charging that the Court was "eager to decide this case" (Id. at 1045), Blackmun first argued that there were both procedural and factual reasons not to have considered the matter, including that it was unlikely there had been a denial of all economically viable use. He then disputed both the majority's announcement of a new categorical rule for denial of all economically viable use and its insistence that only common-law property rules could justify a regulation that had that effect, arguing that "one searches in vain, I think, for anything resembling a principle in the common law of nuisance." 1 d. at 1054

52. Id. at 1065

53. Employment Div., Dept. of Human Res. of Or. v. Smith, 494 U.S. $872,879-80(1990)$

54 . Lucas v. S.C. Coastal Council, 505 U.S. 1003, 1072 n. 7 (1992). Professor Echeveria's article traces the debate between Scalla and Rehnquist on this point; see Echeverria, supra note 5 at 32-33.

55. Dolan v. City of Tigard, 512 U.S. 374 (1994).

56. 1d. at 391 .

57. In fact, the city could not met that burden and ultimately paid Mrs. Dolan $\$ 1.4$ million as part of a settlement to acquire the property dedications it had originally demanded. The settlement also required the city to erect a plaque commemorating Dolan's U.S. Supreme Court victory.

58. Dolan v. City of Tigard, 512 U.S. 374, 411 (1994).

59. 1d. at 413. Souter wrote: "I cannot agree that the application of Nollan is a sound one here, since it appears that the Court has placed the burden of producing evidence of relationship on the city, despite the usual rule in cases involving the police power that the government is presumed to have acted constitutionally."

60. Suitum v. Tahoe Reg'l Planning Agency, 520 U.S. 725 (1997) 61. City of Monterey v. Del Monte Dures, 526 U.S. 687 (1999). 62. Palazzolo v. R.I., 533 U.S. 606 (2001)

63. 1d. at 633

64. Id. at 635 .

65. 1d. at $636-37$

66. Id. at 639

67. 1d. at 645

68. Tahoe-Sierra Pres. Council, Inc. v. Tahoe Reg't Planning Agency, 535 U.S. 302 (2002).

69. Id. at 315-317. The district court found that, given the record in the case regarding the normal time-frame for development in the Lake Tahoe area, "average" purchasers "did not have reasonable, investment-backed expectations that they would be able to build single-family nomes on their land within the six-year period involved in this lawsuit." Id. at 315, citing Tahoe-Sierra

Preservation Council, Inc. v. Tahoe Regional Planning Agency, 34 F.Supp.2d 1226, 1241 (D.Nev. 1999)

70. Tahoe-Sierra Preservation Council, inc. v. Tahoe Regional Planning Agency, 216 F.3d 764 (9th Cir. 2000).

71. Tahoe-Sierra Pres, Council, Inc. v. Tahoe Regional Planning Agency, 535 U.S. 302, 341 (2002)

72. 1d. at 332. Note that Stevens here has stated the Lucas rule as deprivation of all value, not all use, which is how Scalia had framed the rule. Chief Justice Rehnquist's dissent expounded at length on this attempt to change the meaning of Lucas. Id. at 350-351.

73. Lingle v. Chevron U.S.A., Inc., 544 U.S. 528,539 (2005).

74. 1 d. at 540 .

75. Id. at 542 , emphasis in the original.

76. Id. at 546 .

77. 1d, at 548.

78. San Remo Hotel, L.P. v. City and County of San Francisco, 545 U.S. $323(2005)$.

79. Santini v. Conn. Hazardous Waste Mgmt. Serv., 342 F.3d 118, 130 (2nd Cir. 2003)

80 . Kelo v. City of New London, 545 U.S. 469 (2005).

81 . 10 , at 484 .

82. Id. at 504 .

83. Id. at 503

84. Stop the Beach Renourishment, Inc v. Fla. Dep't of Envt'l Prot. et al, 130 S.Ct. 2592 (2010). 


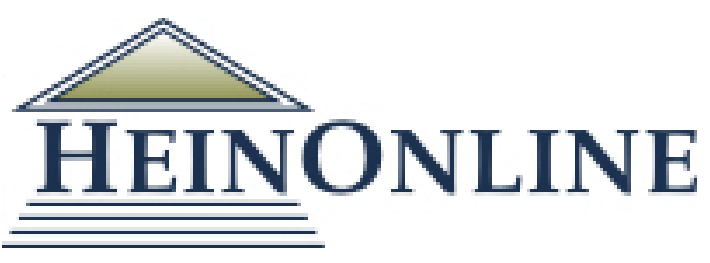

Content downloaded/printed from

HeinOnline

Wed Nov 6 12:33:50 2019

Citations:

Bluebook 20th ed.

Alan Weinstein, Justice John Paul Stevens - His Take on Takings, 62 Planning \& Envtl.

L. 3 (2010).

ALWD 6th ed.

Alan Weinstein, Justice John Paul Stevens - His Take on Takings, 62 Planning \& Envtl. L. 3 (2010).

APA 6th ed.

Weinstein, A. (2010). Justice john paul stevens his take on takings. Planning

Environmental Law, 62(10), 3-14.

Chicago 7th ed.

Alan Weinstein, "Justice John Paul Stevens - His Take on Takings," Planning \&

Environmental Law 62, no. 10 (October 2010): 3-14

McGill Guide 9th ed.

Alan Weinstein, "Justice John Paul Stevens - His Take on Takings" (2010) 62:10

Planning \& Environmental L 3 .

MLA 8th ed.

Weinstein, Alan. "Justice John Paul Stevens - His Take on Takings." Planning \&

Environmental Law, vol. 62, no. 10, October 2010, p. 3-14. HeinOnline.

OSCOLA 4th ed.

Alan Weinstein, 'Justice John Paul Stevens - His Take on Takings' (2010) 62 Planning

\& Envtl L 3

Provided by:

Cleveland-Marshall College of Law Library

-- Your use of this HeinOnline PDF indicates your acceptance of HeinOnline's Terms and Conditions of the license agreement available at https://heinonline.org/HOL/License

-- The search text of this PDF is generated from uncorrected OCR text.

-- To obtain permission to use this article beyond the scope of your license, please use: Copyright Information

Use QR Code reader to send PDF to your smartphone or tablet device

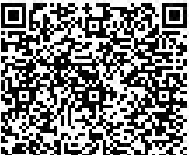

